\title{
SMEs Management Practices in a Hostile Business Environment in Zimbabwe
}

\author{
Bekezela Moyo \\ Department of Business Management, Management College of Southern Africa Botswana \\ P O Box Ad 878 ADD \\ Kgale Postnet Gaborone \\ Botswana \\ Email: bekezelamoyo1@gmail.com
}

Edinah Mandizwidza-Moyo

Faculty of Business, Limkokwing University of Creative Tech

P Bag 0092 Gaborone

Botswana

Email: mmoyoedinah@gmail.com

Received: January 13, 2017 Accepted: February 06, $2017 \quad$ Published: April 10, 2017

doi:10.5296/jebi.v4i1.10722 URL: http://dx.doi.org/10.5296/jebi.v4i1.10722

\begin{abstract}
A great deal of extant literature has emphasised the importance of SMEs role in the economic performance of any country. It is this realization that has propelled almost all countries to nurture their SMEs so as to achieve economic development. This paper intends to interrogate the management practices adopted by SMEs in Zimbabwe, particularly in Gweru metropolitan albeit the macro factors that bedevilled the country to date. To achieve this discussion, emphasis will be drawn to the adoption and adaptation of management practices by these SMEs particularly in four facets: management of human resources, cash management, management of capital assets, and management of the product/service.

This is a conceptual paper and a qualitative research design is going to be used to define the methodology of this paper. A cross sectional survey is proposed for this study, using a sample size of fifty SMEs who will be chosen using purposive and snowballing sampling methods.
\end{abstract}


Questionnaires will be administered on the chosen sample and this will be followed by semi-structured interviews on five cases that will constitute the main cases for discussion and confirmation. Data will be analysed using a thematically data analysis approach as put forth by respondents narrating their encounters.

Keywords: SMEs, Management practices, Hostile business environment, Entrepreneur

\section{Introduction}

Many researchers (Chidoko, Makuyana, Mutungamire, \& Bemani, 2011; Chivasa, 2014; Lourens \& Jonker, 2012; Nyamwanza, 2013; Stokes \& Wilson, 2010; Zimmerer, Scarborough, \& Wilson, 2008) emphasise the important role small businesses bring to the country's economy. There is no doubt that small, micro and medium scale enterprises (SMMEs) play an important role in achieving economic growth of any country through job creation, especially for the unskilled and semi-skilled (Chinomona \& Chinomona, 2013; Kurbah, 2013). Sum, Kow \& Chen (2004) as cited in Nyamwanza (2013, p. 9) posits that "the next phase of economic growth will depend on the stability of home-grown SMEs to develop into large national corporations". Countries like Malta have sustained their economies in the face of the recent recession, through aggressive participation in the economy by small businesses in the country, Bezzina (2010).

Zimbabwe, as a country is no exception to this phenomena and it has made, and continues to make great efforts to grow its SMEs. In its 2015 national budget speech, the government of Zimbabwe indicated that it managed to secure US\$3million line of credit agreement with Arab Bank for Economic Development in Africa (BADEA) for Small and Medium Enterprise Development Corporation (SMEDCO), a conduit established to channel out loans to the SMEs sector (Chinamasa, 2014). Through this fund, the government intended to incubate small businesses through established companies who acted as anchors for small companies providing desired quality controls, technology, and requisite skills. In return, the government would extend to the anchor company incentives such as tax concessions for fostering these SMEs (Chinamasa, 2014).

Since 1997 to date, Zimbabwe has encountered a devastating economic depression resulting in high levels of company closures and retrenchments. Large companies are closing down and others are downsizing their operations, and SMEs have the capacity to absorb people for employment (Zindiye, Roberts-Lombard, \& Herbst, 2008). Zimbabwe economic decline was as a result of the crash in the stock market in November 1997 (Munangagwa, 2009). For the past decade, Zimbabwe has experienced one of its worst periods of economic development and political dynamism since attaining its independence in 1980. This phenomenon is further explained by Bond (2008) who clearly articulates the dramatic economic and political retrogression in Zimbabwe. Though the government has put sanctions imposed by the western countries as the fountain of economic problems, Bond (2008) tends to differ and put forth that sanctions have played a minimal role in economic destruction in Zimbabwe.

The depression of the national economic growth was, in part, catapulted by some economic blue prints recommended to the country through transnational organisations, which started as 
far back as 1990 after attainment of independence in 1980 (Mitlin, 2002). The new economic blue prints tended to follow a liberal and market-driven approach. These included, amongst others, Economic Structural Adjustment Program (ESAP), the Zimbabwe programme for Economic and Social Transformation (ZIMPREST). The envisaged results of these blue prints, though so noble, were quite the opposite practically as this resulted in many formal jobs being lost.

Besides these economic blueprints, other factors that contributed to the collapse of the economy included civil unrest in 1997, the country's participation in the Democratic Republic of Congo in 1998, and the Land Reform Program that was fast tracked in 2000, Munangagwa (2009). Notably large corporations such as Zimbabwe Alloys, Zimbabwe Glass Company, Bata Shoe Company started implementing massive employee retrenchment programmes. Others such as ZimCast, Radar, Kariba Batteries, Cold Storage Commission (CSC) even closed shop as a result of the hyper inflationary environment.

However, the economic depression inversely inculcated a sense of entrepreneurial spirit amongst the population. This was as a result of the "assured monthly income" being lost, as workers lost their formal jobs. The entrepreneurial spirit borne out of the economic down turn as spelt out above witnessed a mushrooming of small business. This scenario is supported by Chirisa, Dumba, and Mukura (2012) who postulated that the greater part of the population relied on engaging in both formal and informal business operations. 5.7 million people are working in the micro, small and medium enterprises (Strassburg \& Khumalo, 2012) and this has drastically contributed towards poverty alleviation (Chirisa et al., 2012; Mudavanhu, Bindu, Chigusiwa, \& Muchabaiwa, 2011; Strassburg \& Khumalo, 2012).

The above scenario of small businesses mushrooming while the large established companies are scaling down or closing shop is intriguing. It triggers anxiety to understand the management practices that are employed by these SMEs to survive the economic turbulence.

\subsection{Research Objective}

a. To investigate the influence of macro environmental factors on management practices employed by SMEs operating in a hostile business environment

b. To evaluate the impact of management practices on the operations of SMEs.

c. To recommend a model that can be adopted by small businesses operating in a hostile business environment

\section{Literature Review}

Smit, Cronje, Brevis, and Vrba (2011, p. 8), describe management as, "the process of planning, organizing, leading, and controlling the scarce resources of the organization to achieve the organization's mission and goals as productively as possible". This definition touches on the four functions of management as spelt out by Fayol (1949), which are still being followed to date. Smit et al. (2011) clarify that these functions seemingly follow a sequential pattern, but however, they happen simultaneously. They formulate a strong foundation from which aspects of good managerial practices can be grounded. 
Management is not only a prerogative of large organisation but also applies to all companies regardless of the size, (Koontz \& Weilhrich, 2010). For the success and survival of any organisation, (especially in a competitive environment) there is need for accurate co-ordination of different activities and resources availed to the organisation. "No business runs in itself, even on momentum" (Murugan, 2011, p. 7).

The four critical frameworks of management rest on planning, organising, leading and control, (Smit et al., 2011) and therefore any discussion on management should initially explore the four dimensions. Planning provides the framework within which coordinating, motivating and controlling can be undertaken (Murugan, 2011). Planning forces an organisation to be proactive, and not reactive (Smit et al., 2011). If plans are in place in an organization, it enables both management and the workforce to focus on attaining the same goals.

Businesses must have specific procedures in place which are aimed at achieving organisational goals, (Nieman \& Bennet, 2004). This will ensure the successful performance of organisational activities and the long term profitability of the organisation. Organising generally, cascades from planning. If the plans have been put in place, structures should be in-line so that these plans can be executed. Without proper and effective structures, plans will never be accomplished. Small businesses are more unstructured compared to medium or large organizations, (Hodgetts \& Kuratko, 2004; Longenecker, Moore, \& Petty, 2004). Organising creates synergies such that all activities taking place in the organisation will become seamless in the thrust to meet the objectives of the organisation.

Leading is important because an individual must know how to influence workers in order to direct their efforts towards the achievement of company goals, (Hodgetts \& Kuratko, 2004). Leading is critical to the organisation as people in the organisation are different. This difference emanates from characteristics such as values and beliefs, interest, personality, capabilities, skills or even attitudes thus making them highly unpredictable and complex Smit et al. (2011). It is therefore paramount that the entrepreneur is aware and capable to address all these issues coming from different people so as to be effective in motivating them to perform in their respective jobs. The knowledge and appreciation of these different characteristics of people by the manager enables him/her to accurately place an employee in the right role to effectively perform and resulting in higher productivity and profitability to the organisation.

Controlling does not exist without previous planning, leading, and organising, (Terry \& Franklin, 2003). It is related to, and a part of, the outputs of the other three fundamental functions of management. Duening and Ivancevich (2003) describe the controlling function as consisting of actions and decisions managers undertake to ensure that actual results are consistent with the desired results. Controlling does not only imply looking at the mechanical or procedural systems in the organisation. It also looks at the human resource element in terms of behavior change that will suit the achievement of organisational goals, (Hodgetts \& Kuratko, 2004). Controls help maintain or redirect actual behaviors and results in order to maximize the outputs of individuals and work teams in an organisation (Hellriegel et al., 2004). 


\subsection{Business Environment}

An enterprise is affected by so many factors in its quest to fulfill its obligations, some of these forces are within its capability to influence, yet some are far aloof for the organisation to influence. Therefore an understanding of these factors prepares an organisation to effectively deal with these forces.

Johnson, Scholes, and Whittington (2008), describe that the environment is the one that gives means of survival to the organisation, and it also presents sources of threats to it as well. As for SMEs, the competitiveness existing in their industries, forces them to become more proactive. There is a need that they continuously explore the most efficient ways of trying to best serve their customers and improve either on the product or service which they provide in the market. It is important to explore the macro environment so as to take advantage or become proactive to all those adverse effects brought by these forces. This has a direct impact on the profitability and growth of a business (Kotha \& Nair, 1995; Wagner \& Gooding 1997) as cited in (Ahmad, 2012).

The macro environment is made up of four elements namely the political, economic, social, and technological (Kotler \& Keller, 2012). Political, which at times is referred to as legal, consists of laws, government agencies, and pressure groups that influence or limit various organisations and individuals in a given society (Kotler \& Keller, 2012). Since the launch of Economic Structural Adjustment Programme (ESAP) in 1990, Zimbabwe has been marked with a precipitous economy that has resulted in an unsustainable business environment (Chirisa et al., 2012). This has caused a great challenge for businesses to navigate themselves out of the storm. One typical example is "Murambatsvina", an erratic policy by the government in trying to salvage the economy, saw the destruction of 700000 small businesses and enterprises throughout the country (Tibaijuka, 2005; Chirisa 2009) as cited in (Chirisa et al., 2012).

Economic environment consists of factors that affect consumer purchasing and spending patterns (Kotler \& Keller, 2012). The Poverty Assessment Study Survey (PASS) was last conducted in Zimbabwe since 2003 and it revealed that $72 \%$ of the population was living below the poverty line (Ministry of Public Service, 2006). Other estimates posit that since the economic crisis reached its peak in November 2008, up to $80 \%$ of the population survived on less than $\$ 2$ per day (Chimhowu, Manjengwa, \& Feresu, 2010). These above statistics are an indicator of how dire the country's economy is.

Social/cultural environment is made up of institutions and other forces that affect a society's basic values, perceptions, preferences, and behaviors (Kotler \& Keller, 2012). It includes other aspect such as customs, traditions, values, beliefs, poverty, literacy and life expectancy. Some of the notable activities that can be influenced by this factor might include stocking levels that can be triggered by certain seasonal episodes such as Christmas time when generally people indulge in high levels of shopping. It is critical for any business to note all these factors as they have a direct influence in their operations.

The technological environment changes quite rapidly and includes the methods, techniques 
and approaches that are used in the production of goods and services, including their distribution too. For any business to remain competitive, it has to embrace the changes that are taking place within this environment. Such changes can bring about low levels of production costs, improve on product quality hence enable the organisation to charge a premium price for the product leading to high profitability.

\subsection{The Immediate Environment}

It is critical that an organisation scrutinize its immediate environment, which is at times referred to as the internal environment, so as to take advantage of opportunities that avail themselves as well as promptly adjust itself against adverse forces that might affect its operations. Internal environment is described by the organisational structure, resources, climate, and culture (Tang, 1998). Some other authorities (J. B. Barney \& Hesterly, 2012; Hitt, A, \& Hoskinsson, 2003; Pearce \& Robinson, 2013; Thompson, Strickland, \& Gamble, 2010) include the resources, capabilities and competencies, held by the company, in their analysis of the internal environment. They qualify this as Resource Based View (RBV) approach. Mainly the essence is to look at the strengths and weaknesses of the organisation.

However it is also important to mention that immediate environment can be categorized into two perspectives i.e. the one dealing with internal constituents of the firm as explained by the RBV approach, and the other dealing with the industry from where the firm is operating as explained through Porter Five Forces model (Porter, 1980). The five forces mainly include threat of new entrants, bargaining power of suppliers, bargaining power of customers, and threat of substitutes. Much of the discussion on this paper will be based on the RBV approach because of the management practices that have been identified as constituting the main framework of this discourse. RBV approach tends to clarify why firms in the same industry, differ in terms of competitiveness, due to their unique bundle of resources and capabilities ( $\mathrm{J}$. Barney, 1991; Peteraf, 1993; Wernerfelt, 1984).

\subsection{Management Practices}

This paper intends to look at how small businesses manage human resources at its disposal, management of its cash resources, management of capital assets that it has acquired, and management of its products/services. Small enterprises operate on lean budgets, they are not able to hire qualified staff with vast knowledge in managing the enterprise, and therefore, the management of such enterprises is left to the owners, who lack these professional skills in management (Dzansi, 2004). It is therefore intriguing to find out how these small businesses survive in volatile environments despite lack of professional skills.

A competent workforce is perhaps the most important asset for any organisation hence the need of any company, regardless of the size, to positively focus on human resources (Das, Narendra, \& Mishra, 2014). Small companies tend to adopt less use of high performance Human Resources Management (HRM) practices than large organisations hence allowing them flexibility in their operations (Hornsby \& Kuratko, 1990; M.Barron, Black, \& Loewenstein, 1987). Practice of HRM in SMEs consist of non-structured training, compensation, recruiting and selection of employees (Kotey \& Slade, 2007). Smaller firms 
should be more flexible and informal to be able to cope with the higher levels of environmental uncertainty.

The implementation of sound cash management practices is essential to ensure profitability and sustainability of any successful business as large number of businesses fail due to the absence of cash rather than the absence of profits (Mungal \& Garbharran, 2014). They go further to posit that many small businesses find cash management practices as unnecessary and time consuming. In this discourse, cash management includes current liabilities (the creditors) and current assets (the debtors).

In most organisations, there are cash inflows and cash outflows and therefore these money movements seek for astute financial management for the entity to survive and grow even in turbulent times. Most small business owners lack prerequisite skills and tools for financial management in their operations (Mungal \& Garbharran, 2014). About 70\% of small businesses relay on in-house debt collection methods thus bringing in an inconsistent pattern of cash in-flows (Mungal \& Garbharran, 2014). This on itself brings in challenges in planning for future by small businesses. In credit payment, to suppliers, most small businesses struggle to pay in time thus forcing the suppliers to add enormous interest on the principal owing and this, at the end of the day becomes more expensive to the small businesses, impacting it negatively in profit making. The combination of debtors' management strategy, cash management, account payable (or creditors) and most importantly stock management strategy left much to be desired by the SMEs (Sunday, 2011).

However good cash management prevents bankruptcy and thus increase profitability and sustainability of businesses (Attom \& Mbroh, 2012). Astute cash management will help the small business to take advantage of some of the opportunities that might avail themselves in the operating environment. It might also cushion itself against any adverse conditions in the environment too.

Asset management is integral to any business regardless of the size as it lowers its cost base thus increasing on its profitability. A study by KPMG (United Kingdom) has revealed that businesses were wasting $£ 17 \mathrm{bn}$ annually through absence of proper asset management controls (Moody, 2003). Such a high monetary figure is indicative of how serious asset management controls are to any organisation. According to Marketwire (2013), as cited in Mungal and Garbharran (2014), $73 \%$ of small businesses surveyed indicated that they have no inventory control systems. Most of these small businesses intuitively kept these inventory data in their memory.

Empirically some of the small businesses are grossly under using some of the equipment involved in the production processes. This might be due to lack of ability to operate the equipment emanating from literacy levels. Equipment or assets in this regard include amongst others, computers, printers, photocopiers, and general premises where the business is operating from. Premises involve full and effective utilization of space. It is therefore more prudent not to keep idle assets for prestige purposes, but rather sell them and convert the proceeds for other investments that can bring in income to the organisation. 


\section{Macrothink Institute $^{\mathrm{TM}}$}

Management of product/service lies in the heart of any organisation. Product is anything that can be offered to a market to satisfy a want or a need (Kotler \& Keller, 2012). Most of the small businesses tend to sell omnibus products and therefore there is little or no differentiation amongst their market offering or even branding their products as a way of showing ownership. This therefore tends to erode the profits that they can make in the market by not charging premium prices for their products due to similarities of these products. Product innovation is one way they can use to charge premium prices. Innovation is a function of the firm's ability to manage, maintain, and create knowledge (Cohen and Levinthal 1990; Smith, Collins, and Clark 2005) as cited in Maes and Sels (2014).

Innovation management refers to an organisation's efforts to discover and manage new products and/or service opportunities and to make improvements to existing processes and systems (Cooper and Kleinschmidt, 1997) as cited in Sciascia, Nordvist, Mazzola, and Massis (2015). At times innovation may be termed as new product development (NPD). NPD programmes can be much more effective as growth strategy of any firm as compared to other strategies such as mergers, alliances, acquisitions, or joint venture (Jones, McCormick, \& Dewing, 2012). Product or service innovation brings in a competitive advantage to the organisation, and therefore this might work well for those organisations who are involved in a highly competitive environment.

\subsection{Conceptual Framework}

"Conceptual or theoretical model is a simplified systematic conceptual structure of interrelated elements in some schematic form such as narrative statement or mathematical equation. It describes relationships between and among concepts and variables", (Krishnaswami \& Ranganatham, 2007, p. 16). This paper will therefore be based on the following conceptual framework.

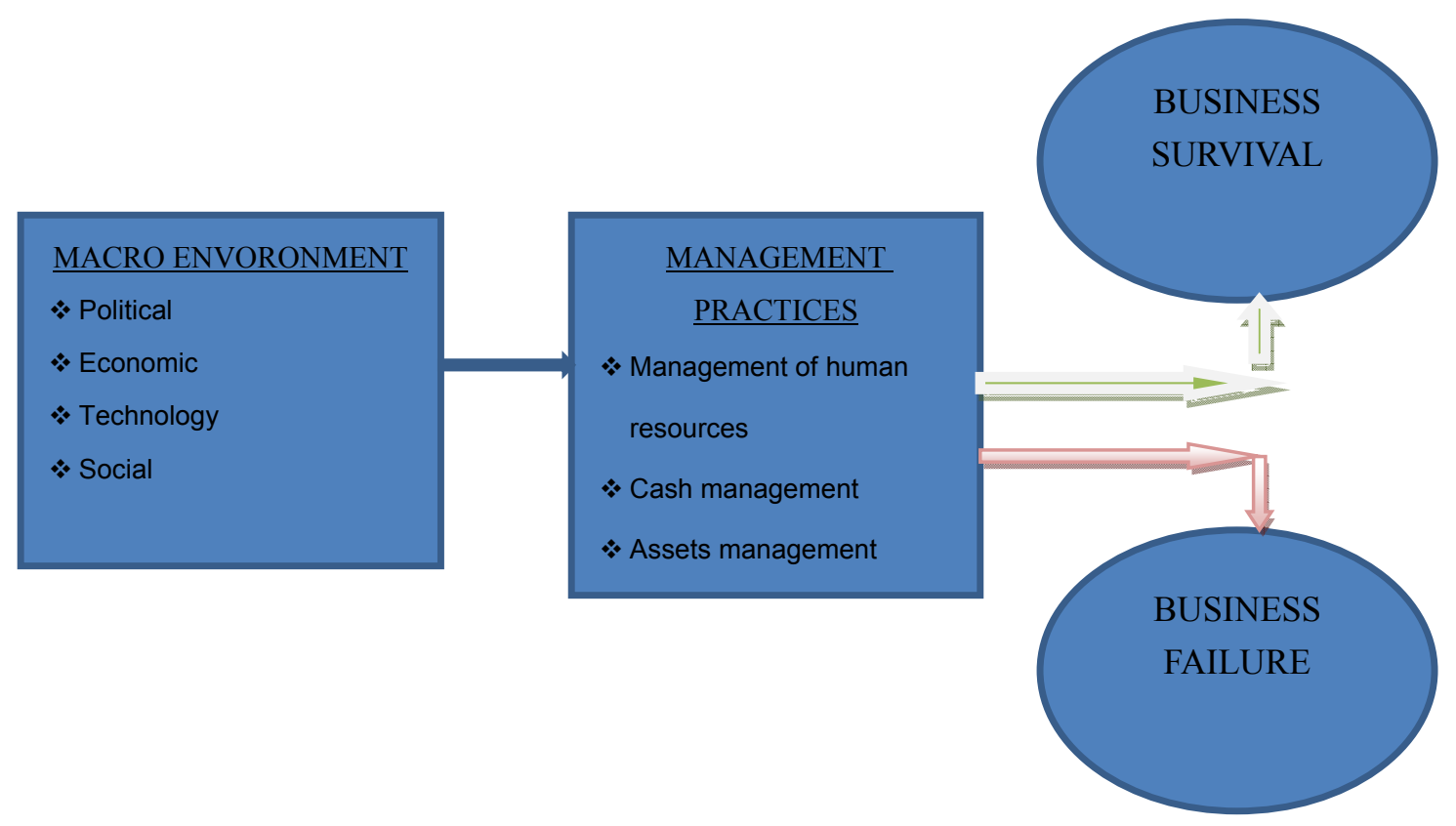

Figure 1. Conceptual framework 
Considering the literature review discussed above, as well as the conceptual framework also depicted above, both combined and influenced by the research objective, this study will attempt to test the applicability of management practices through the following hypothesis:

H1: "Macro environmental factors are significantly and positively related to management practices.

\section{Research Design}

The study will adopt a qualitative approach based on 10 case studies of SMEs in five different sectors, operating in Gweru. An exploratory research approach will also be utilised in exploring the contextual richness and in explaining the complexities of management practices construct underpinning the study. Purposive sampling techniques will be utilized to select the 10 case studies, two cases from each sector: retail, service, manufacturing, information \& communication technology and construction sectors.

Furthermore, the study will employ in-depth interviews, observation and document analysis to facilitate for richer data collection from the participants. The in-depth interviews will be done with the owners of the SMEs; the managers in cases where the owner is not the manager of the SME and the employees of the SME. This will enable the collection of diverse perspectives of management practices from different groups of respondents.

The interview protocol for the study requires a minimum of two interviews with each case and in some cases multiple interviews will be conducted. The initial interview will facilitate for more in-depth-holistic data collection through further probing questions. The follow up interviews will enable the study to collect additional information or further clarity to be done on information collected from the first interview. However, the study will endeavour to minimise the number of follow up interviews as SMEs are generally time constrained and busy.

Under observation, the study will dedicate two days per each case SME to observe how the owners, managers and staff interact and behave with each other, with customers, products, manage assets and handle cash in the business. Informed consent will be sought with the owners of the SMEs before observations take place but the parties being observed will not be aware of when the observations will take place; so as to eliminate the 'staged performance' by the participates. In addition, document analysis will be done of the non confidential documents of the SME such as vision \& mission statements, advertisements, procedure manuals, handbooks and press statements. These will also be analysed after seeking consent from the owners of the SMEs.

Data analysis involves the separation of things (sic) into their component parts. It calls on the researcher to discover the key components or general principles underlying a particular phenomenon so that these can be used to provide a clearer understanding of that thing and analyse the patterns, themes and categories that emerge from the data (Saunders, Lewis, \& Thornhill, 2009). NVIVO 10 and SPSS software packages will be utilized to analyze \& present the data. 


\section{Macrothink}

\section{Limitations}

Despite careful selection of the 10 SMEs for the study, generalization of the research findings across all SMEs in Zimbabwe will not be possible due to the small sample size and to the fact that other sectors were left out from the study. Secondly, the 10 SMEs are located in the Gweru metropolitan area thus are only representative of the SMES in the urban areas. Therefore, the study findings cannot also be generalized to SMEs operating in the rural and semi-rural areas.

\section{References}

Ahmad, A. E. M. K. (2012). Macro-environment Influences on Health Service Strategy in Saudi Private Sector Hospitals: An Empirical Investigation. International Business Research, $5(5)$.

Attom, B. E., \& Mbroh, J. K. (2012). Financial Management Made Easy. Accra: Adwinsa Publications $(\mathrm{GH})$ Ltd.

Barney, J. (1991). Firm resources and sustained competitive advantage. Journal of Management, 17(1), 99-120.

Barney, J. B., \& Hesterly, W. S. (2012). Strategic Management and Competitive Advantage (3rd ed.). United States of America: Pearson Prentice Hall.

Bezzina, F. (2010). Characteristics of the Maltenese Entrepreneurs. International Journal of Arts and Sciences, 3(7), 292-312.

Bond, P. (2008). Lessons of Zimbabwe: An exchange between Patrick Bond and Mahmood Mamdani. Links International journal of Socialist renewal. Retrieved from http://links.org.au/node/815 website

Chidoko, C., Makuyana, G., Mutungamire, P., \& Bemani, J. (2011). Impact of the Informal Sector on the Current Zimbabwean Economic Environment. International Journal of Economics and Research, 26-28.

Chimhowu, A., Manjengwa, J., \& Feresu, S. (2010). Moving Forward in Zimbabwe: Reducing Poverty and Promoting Growth. Harare: Institute of Environmental Studies / Brooks World Poverty Institute (BWPI).

Chinamasa, P. (2014). The 2015 National Budget Statement. Harare.

Chinomona, R., \& Chinomona, E. (2013). The influence of employees' perceptions of organizational politics on turnover intentions in Zimbabwe's SME sector. South African Journal of Business Management, 44(2), 57-66.

Chirisa, I., Dumba, S., \& Mukura, T. (2012). Innovative, Adaptive and Survivalist Strategies by Small Business Enteprises in Zimbabwe (1990- 2009): Implications for Policy and Planning. International Journal for Academic Research in Business and Social Sciences, 2. 


\section{Macrothink}

Journal of Entrepreneurship and Business Innovation

ISSN 2332-8851 2017, Vol. 4, No. 1

Chivasa, S. (2014). Entrepreneurship Culture among SMEs in Zimbabwe: A Case of Bulawayo SMEs. International Journal of Economics, Commerce and Management, 2(9).

Das, S. P., Narendra, P., \& Mishra, P. (2014). Human resource issues in Small \& Medium Enterprises- A Literature Review. International Journal of Research in Humanities, Arts and Literature, 2(5), 183-194.

Duening, T. N., \& Ivancevich, J. M. (2003). Management Principles \& Guidelines. United States of America: Atomic Dog Publishing.

Dzansi, D. Y. (2004). Social Responsibility of SMEs in Rural Areas. (Doctoral), University of Pretoria, South Africa.

Hellriegel, D., Jackson, S. E., Slocum, J., Staude, G., Amos, T., Klopper, H. B., . . . Oosthuiizen, T. (2004). Management. Oxford: University Press.

Hitt, M., A, R. D. I., \& Hoskinsson, R. E. (2003). Strategic Management: Welcoming the Era of Competition and Globalization. Jakarta: The Publisher.

Hodgetts, R. M., \& Kuratko, D. F. (2004). Entrepreneurship: Theory, Process, and Practice. London: Harcourt College Publisher.

Hornsby, J. S., \& Kuratko, D. K. (1990). Human Resource Management in Small Business: Critical Issues for the 1990s. Journal of Small Business Management, 28(3).

Johnson, G., Scholes, K., \& Whittington, R. (2008). Exploring Corporate Strategy: Text and Cases. England: Pearson Education Limited.

Jones, T., McCormick, D., \& Dewing, C. (2012). Growth Champions-the Battle for Sustained Innovation Leardership. Chichester: John Wiley and Sons.

Koontz, H., \& Weilhrich, H. (2010). Essentials of Management (8th ed.). New Delhi: McGraw Hill.

Kotey, B., \& Slade, P. (2007). Employee Training in SMEs: Effect of Size and Firm Type-Family and Nonfamily. Journal of Small Business Management, 45(2), 214-238.

Kotler, P., \& Keller, K. L. (2012). Marketing Management (14th ed.). Upper Saddle River, New Jersey: Prentice-Hall.

Krishnaswami, O. R., \& Ranganatham, M. (2007). Methodology of Research in Social Sciences. Mumbai: Himalaya Publishing House.

Kurbah, S. (2013). Role of Women Entrepreneurs in the Economic Development of Meghalaya: A North Eastern State, India. International Journal of Engineering, Business and Enterprise

Applications, 13-156.

Longenecker, J. G., Moore, C. W., \& Petty, J. W. (2004). Small Business Management- An Entrepreneurial Emphasis. South- Western: Thomson. 


\section{Macrothink}

Journal of Entrepreneurship and Business Innovation

ISSN 2332-8851

2017, Vol. 4, No. 1

Lourens, A. S., \& Jonker, J. A. (2012). THE STRATEGIC RELEVANCE OF TECHNOLOGY-RELATED VARIABLES TO THE COMPETITIVENESS OF SMALL TO MEDIUM-SIZED FURNITURE MANUFACTURERS. South African Journal of Industrial Engineering, 23(3), 180-195.

M.Barron, J., Black, D. A., \& Loewenstein, M. A. (1987). Employer Size: the Implications for Search, Training, Capital Investment, Starting Wages, and Wage Growth. Journal of Labor Economics, 5(1).

Maes, J., \& Sels, L. (2014). SMEs' Radical Product Innovation: The Role of Internally and Externally Oriented Knowledge Capabilities. Journal of Small Business Management, 52(1), 141-163.

Ministry of Public Service, L. a. S. W. (2006). Zimbabwe 2003 Poverty Assessment Study Survey Main Report. Harare.

Mitlin, D. (2002). Sustaining markets or poverty reduction. Environment and Urbanisation, 14(1), 173-177.

Moody, A. (2003). Working your Assets. 57(3), 34-34.

Mudavanhu, V., Bindu, S., Chigusiwa, L., \& Muchabaiwa, L. (2011). Determinants os Small and Medium Enterprises Failure in Zimbabwe: A Case Study of Bindura. International Journal of Economics and Research, 2(5), 82-89.

Munangagwa, C. L. (2009). The Economic Decline of Zimbabwe. Gettysburg Economic Review, 3(1).

Mungal, A., \& Garbharran, H. L. (2014). Cash Management Challanges of Small Businesses in a Developing Community. Mediterranean Journal of Social Sciences, 5(27).

Murugan, S. M. (2011). Management Principles and Practices. New Delhi: New Age International Ltd.

Nieman, G., \& Bennet, A. (2004). Business Management- A Value Chain Approach. Pretoria: Van Schaik Publishers.

Nyamwanza, T. (2013). A Vision Setting among Zimbabwean SMEs And Its Impact on SMEs' Survival and growth. The International Journal of Business and Management, 1(6), 8-13.

Pearce, J. A., \& Robinson, R. B. (2013). Startegic Management: Planning for Domestic \& Global Competition (13th ed.). New York: McGraw-Hill Companies.

Peteraf, M. (1993). The cornerstones of competitive advantage: A resource based view. . Strategic Management Journal, 14(3), 179-191.

Porter, M. (1980). Competitive Strategy: Techniques for Analyzing Industries and Competitors. New York: The Free Press. 


\section{Macrothink}

Journal of Entrepreneurship and Business Innovation

ISSN 2332-8851

Saunders, M., Lewis, P., \& Thornhill, A. (2009). Research Methods for Business Students (5th ed.). England: Pearson Education Limited.

Sciascia, S., Nordvist, M., Mazzola, P., \& Massis, A. D. (2015). Family Ownership and R\&D Intensity in Small- and Medium-Sized Firms. Product Development \& Management Association, 32(3), 349-360.

Smit, P. J., Cronje, G. J., Brevis, T., \& Vrba, M. (2011). Management Principles. Cape Town, Republic of South Africa: Junta and Company Ltd.

Stokes, D., \& Wilson, N. (2010). Small Business Management and Entrepreneurship (6th ed.). United Kingdom.

Strassburg, S., \& Khumalo, J. (2012). FinScope MSME Survey Zimbabwe Zimbabwe: FinMark Trust.

Sunday, K. J. (2011). Effective Working Capital Management in Small and Medium Scale Enterprises (SMEs). International Journal of Business Administration, 6(9).

Tang, H. (1998). An integrative model of innovation in organizations. Technovation, 18(5), 297-309.

Terry, G. R., \& Franklin, S. G. (2003). Principles of Management (8th ed.). Krishan Nagar, Delhi: A.I.T.B.S. Publishers \& Distributors.

Thompson, A. A., Strickland, A. J., \& Gamble, E. J. (2010). Crafting and Executing Strategy The Quest for Competitive Advantage: Concept and Cases (17th ed.). United States of America: The McGraw Hill company.

Wernerfelt, B. (1984). A resource based view of the firm. Strategic Management Journal, $5(2), 171-180$.

Zimmerer, T. W., Scarborough, N. M., \& Wilson, D. (2008). Essentials of Entrepreneurship and Small Business Management (5th ed.). New Jersey: Pearson Education.

Zindiye, S., Roberts-Lombard, M., \& Herbst, G. (2008). An Empirical Investigation into the Factors Affecting the Performance of SMEs in the Manufacturing Sector of Harare, Zimbabwe (Masters Thesis ), University of Fort Hare,, South Africa.

\section{Copyright Disclaimer}

Copyright for this article is retained by the author (s), with first publication rights granted to the journal.

This is an open-access article distributed under the terms and conditions of the Creative Commons Attribution license (http://creativecommons.org/licenses/by/3.0/). 